\title{
Seventeen new dragonfly records from Colombia and the confirmation of the synonymy of Philogenia monotis and $P$. tinalandia (Insecta: Odonata)
}

\author{
Cornelio A. Bota-Sierra (DD, ${ }^{\mathrm{a}, \mathrm{b}}{ }^{\dagger}$, Andrea Corso $^{\mathrm{c}}$, Ottavio Janni ${ }^{\mathrm{d}}$, Juliana Sandoval-H. (DD ${ }^{\mathrm{a}}$ and \\ Michele Viganò ${ }^{\mathrm{e}}$ \\ ${ }^{a}$ Red de Biodiversidad y Sistemática, Instituto de Ecología, A.C. Xalapa, Mexico; ${ }^{b}$ Grupo de Entomología \\ Universidad de Antioquia (GEUA), Universidad de Antioquia, Medellin, Colombia; ${ }^{c}$ MISC, Siracusa, \\ Italy; ${ }^{d}$ MISC, Piedimonte Matese, Caserta, Italy; ${ }^{e}$ MISC, Germignaga, Varese, Italy
}

(Received 11 December 2017; accepted 4 April 2018)

\begin{abstract}
During 2.5 months of intensive fieldwork in Colombia (departments of Cauca, Nariño, and Putumayo, South America) from January to March 2017, we visited 13 localities and collected 291 specimens of 68 species of Odonata, including 17 new records for the country. We report range expansions for several species assessed as data deficient or under some degree of threat by the IUCN Red List. Furthermore, we confirmed that Philogenia tinalandia is a junior synonym of $P$. monotis, thus solving a longstanding enigma. We also report the rediscovery, after many decades, of Philogenia raphaella, . sucra and Stenocora percornuta. The data we collected are an important contribution to the knowledge of the dragonfly diversity of the Colombian Andean region and its surroundings, including the nearby areas in Ecuador and Peru, countries with which the departments visited share boundaries.
\end{abstract}

Keywords: Cauca; diversity; damselfly; Nariño; Putumayo

\section{Introduction}

Colombia is a tropical country and one of the most biodiverse nations in the world thanks to its geography and geological history. It is located at the confluence of the Amazon and Central American biotas, while the three Andean Cordilleras that cross the country from southwest to northeast result in a wide range of habitats: from hot tropical forest in the lowlands to cold glaciers at the top of the highest mountains (Rangel-ch, 2005). In spite of this, Colombia remains one of the least biologically explored countries in the world (Paulson, 2004). Even in charismatic groups such as birds, new species for science and new country records continue to be regularly discovered (Avendaño et al., 2015; Lara, Cuervo, Valderrama, Calderón-f, \& Cadena, 2012; Stiles, Laverde-R, \& Cadena, 2017). Dragonflies (Odonata) are no exception: its country list of 406 species (Bota-Sierra, 2017; Bota-Sierra, Moreno-Arias, \& Faasen, 2015; Bota-Sierra \& Novelo-Gutiérrez, 2017; Garrison \& von Ellenrieder, 2015, 2017; Rache, 2015) clearly lags behind its neighbors Peru, with 553 species (Bota-Sierra, Maufray, et al., 2016; Hoffmann, 2009), and Venezuela, with 525 (Vivas-Santeliz \& De Marmels, 2017).

\footnotetext{
*Corresponding author. Email: corneliobota@gmail.com

$\dagger$ These authors contributed equally to this work.
} 


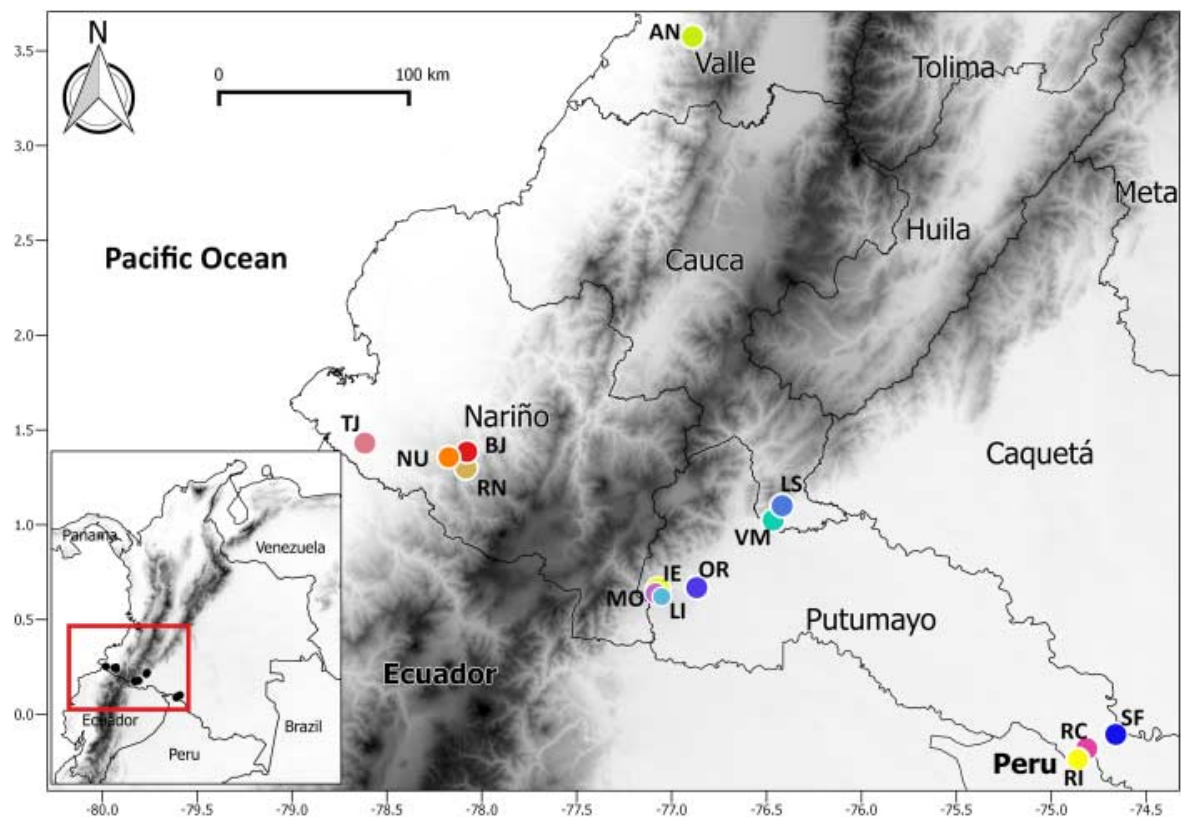

Figure 1. Map showing the localities were the specimens were collected: OR, Orito town; IE, La Isla Escondida Natural Reserve; MO, trail Orito-Monopamba; LI, El Libano township; RC, Río Caucayá; SF, San Francisco township; RI, Putumayo River (river island); VM, Miraflores township; LS, La Sevilla township; RN, Nambí Natural Reserve; BJ, Road Barbacoas-Junin; NU, Road Tumaco- Junin (close to La Nutria Natural Reserve); TJ, Km 42 Road Tumaco-Junin.

Southwestern Colombia, near the border with Ecuador, is one of the least explored areas in the country. It comprises the departments of Cauca, Nariño, and Putumayo, with elevations ranging from sea level along the Pacific Ocean to $4764 \mathrm{~m}$ at Cumbal Volcano in the Andes. The region harbors a great variety of habitats from lowland and foothill rainforest in the Amazonian (east of the Andes) and Chocó biomes (west of the Andes), cloud forests, dry forests in the Patía Valley, and several páramos, high-mountain ecosystems unique to the tropical Andes (see Figure 1). The odonate fauna of the departments of Cauca, Nariño and Putumayo is nearly unknown, as attested by their respective species totals of six, 17 and 35 (Bota-Sierra, 2014; Bota-Sierra et al., 2015; Bota-Sierra, Rache, \& Palacino, 2016; Pérez-Gutiérrez \& Palacino-Rodríguez, 2011), certainly a tiny fraction of the true diversity of such an ecologically rich area. These departments had been poorly explored, in part because of political unrest, but in light of recent drastic improvements in the security situation, we decided to target them for fieldwork in order to uncover some of the diversity harbored by the region and shed light on the great richness of species that has been previously disregarded in the area. Here we present the results of our expedition, including 17 species new to Colombia, the confirmation of a previously suggested synonymy and the rediscovery of three species many decades after the last known records. Additionally, we present a map with the sampled localities, photographs and natural history notes for the species recorded during the study.

\section{Methods}

\section{Study area}

During 2.5 months of travel, from 4 January to 25 March 2017, we visited 13 localities that ranged from 50 to $1350 \mathrm{~m}$ in elevation and from 2929 to $6923 \mathrm{~mm}$ of rainfall (Hijmans, Cameron, 
Table 1. Localities visited during the trip. For any visited site we report department, locality name, locality code, habitat studied, coordinates, altitude, annual average precipitation and date of field activities.

\begin{tabular}{|c|c|c|c|c|c|}
\hline Department & Locality & Locality code & Habitats for Odonata & $\begin{array}{l}\text { Coordinates, altitude, and } \\
\text { annual average precipitation }\end{array}$ & $\begin{array}{l}\text { Date of field } \\
\text { activities (in 2017) }\end{array}$ \\
\hline Putumayo & $\begin{array}{l}\text { Municipality of } \\
\text { Orito, Orito town outskirts }\end{array}$ & OR & Wet pastures & $\begin{array}{l}0.66792^{\circ} \mathrm{N} 76.86758^{\circ} \mathrm{W} \\
350 \mathrm{~m} \\
3341 \mathrm{~mm}\end{array}$ & 14 Jan \\
\hline Putumayo & $\begin{array}{l}\text { Municipality of } \\
\text { Orito, Reserva Natural La Isla Escondida }\end{array}$ & IE & $\begin{array}{l}\text { Medium to fast-flowing streams and rivulets } \\
\text { in foothill forest }\end{array}$ & $\begin{array}{l}0.65775^{\circ} \mathrm{N} 77.07216^{\circ} \mathrm{W} \\
650-950 \mathrm{~m} \\
3351 \mathrm{~mm}\end{array}$ & 15-20 Jan; 3-23 Mar \\
\hline Putumayo & Municipality of Orito, trail to Monopamba & $\mathrm{MO}$ & $\begin{array}{l}\text { Fast-flowing streams and rivulets in patchy } \\
\text { foothill forest and pastures }\end{array}$ & $\begin{array}{l}0.63825^{\circ} \mathrm{N} 77.08447^{\circ} \mathrm{W} 700 \mathrm{~m} \\
3241 \mathrm{~mm}\end{array}$ & $21 \mathrm{Jan}$ \\
\hline Putumayo & $\begin{array}{l}\text { Municipality of } \\
\text { Orito, Vereda El Libano }\end{array}$ & LI & Streams and seeps in foothill forest & $\begin{array}{l}0.62038^{\circ} \mathrm{N} 77.05247^{\circ} \mathrm{W} \\
600-700 \mathrm{~m} \\
3389 \mathrm{~mm}\end{array}$ & 22 Jan \\
\hline Putumayo & $\begin{array}{l}\text { Municipality of } \\
\text { Puerto Leguizamo, mouth of Rio Caucayá }\end{array}$ & $\mathrm{RC}$ & $\begin{array}{l}\text { Varzea forest and small marshes bordered by } \\
\text { pastures }\end{array}$ & $\begin{array}{l}0.18128^{\circ} \mathrm{S} 74.81289^{\circ} \mathrm{W} \\
190 \mathrm{~m} \\
2981 \mathrm{~mm}\end{array}$ & 29 Jan \\
\hline Putumayo & $\begin{array}{l}\text { Municipality of Puerto Leguizamo, Vereda San } \\
\text { Francisco }\end{array}$ & $\mathrm{SF}$ & $\begin{array}{l}\text { Streams and small ponds in lowland } \\
\text { Amazonian terra firma rainforest and } \\
\text { cattle pastures }\end{array}$ & $\begin{array}{l}0.10647^{\circ} \mathrm{S} 74.65983^{\circ} \mathrm{W} \\
190 \mathrm{~m} \\
3062 \mathrm{~mm}\end{array}$ & 30 Jan \\
\hline Putumayo & $\begin{array}{l}\text { Putumayo River, Municipality of Puerto } \\
\text { Leguizamo, river island } 9 \mathrm{~km} \text { upstream from } \\
\text { Puerto Leguizamo }\end{array}$ & RI & $\begin{array}{l}\text { Sandbar on the river with early successional } \\
\text { vegetation, some of it flooded }\end{array}$ & $\begin{array}{l}0.23634^{\circ} \mathrm{S} 74.85961^{\circ} \mathrm{W} 180 \mathrm{~m} \\
2929 \mathrm{~mm}\end{array}$ & 29 and 31 Jan \\
\hline Cauca & $\begin{array}{l}\text { Municipality of Piamonte, Finca Mirasol, } \\
\text { Vereda Miraflores, foot of the Serranía de los } \\
\text { Churumbelos }\end{array}$ & $\mathrm{VM}$ & $\begin{array}{l}\text { Streams and ponds fringed by strips of forest } \\
\text { in largely deforested Amazonian lowlands }\end{array}$ & $\begin{array}{l}1.02422^{\circ} \mathrm{N} 76.46517^{\circ} \mathrm{W} 300 \mathrm{~m} \\
\quad 4141 \mathrm{~mm}\end{array}$ & 23-24 Jan \\
\hline Cauca & $\begin{array}{l}\text { Municipality of Piamonte, Vereda La Sevilla, } \\
\text { foothills in the Serranía de los Churumbelos }\end{array}$ & LS & Streams in foothill forest & $\begin{array}{l}1.10000^{\circ} \mathrm{N} 76.41750^{\circ} \mathrm{W} \\
450 \mathrm{~m} \\
4256 \mathrm{~mm}\end{array}$ & 25-26 Jan \\
\hline
\end{tabular}


Table 1. Continued.

\begin{tabular}{|c|c|c|c|c|c|}
\hline Department & Locality & Locality code & Habitats for Odonata & $\begin{array}{l}\text { Coordinates, altitude, and } \\
\text { annual average precipitation }\end{array}$ & $\begin{array}{c}\text { Date of field } \\
\text { activities (in 2017) }\end{array}$ \\
\hline Nariño & $\begin{array}{l}\text { Municipality of Barbacoas, Reserva Natural Rio } \\
\text { Ñambí }\end{array}$ & RN & Streams and rivulets in cloud-forest & $\begin{array}{l}1.29853^{\circ} \mathrm{N} 78.08317^{\circ} \mathrm{W} \\
1350 \mathrm{~m} \\
3570 \mathrm{~mm}\end{array}$ & $17 \mathrm{Feb}$ \\
\hline Nariño & $\begin{array}{l}\text { Municipality of Barbacoas, road Barbacoas- } \\
\text { Junin }\end{array}$ & BJ & $\begin{array}{l}\text { Road-side vegetation close to well preserved } \\
\text { forests }\end{array}$ & $\begin{array}{l}1.38450^{\circ} \mathrm{N} 78.07783^{\circ} \mathrm{W} \\
1000 \mathrm{~m} \\
5026 \mathrm{~mm}\end{array}$ & $18 \mathrm{Feb}$ \\
\hline Nariño & $\begin{array}{l}\text { Municipality of Barbacoas, road Tumaco-Junin, } \\
\text { close to Reserva la Nutria }\end{array}$ & NU & $\begin{array}{l}\text { Road-side vegetation close to well preserved } \\
\text { forests }\end{array}$ & $\begin{array}{l}1.35558^{\circ} \mathrm{N} 78.17450^{\circ} \mathrm{W} \\
800 \mathrm{~m} \\
6923 \mathrm{~mm}\end{array}$ & $18 \mathrm{Feb}$ \\
\hline Nariño & $\begin{array}{l}\text { Municipality of Tumaco, } \mathrm{km} 42 \text { on the } \\
\text { Tumaco-Junín road }\end{array}$ & TJ & $\begin{array}{l}\text { Road-side vegetation and channels in mixed } \\
\text { forest and pastures }\end{array}$ & $\begin{array}{l}1.43022^{\circ} \mathrm{N} 78.61669^{\circ} \mathrm{W} \\
50 \mathrm{~m} \\
3132 \mathrm{~mm}\end{array}$ & $18 \mathrm{Feb}$ \\
\hline
\end{tabular}


Parra, Jones, \& Jarvis, 2005), in the departments of Cauca, Nariño and Putumayo (Table 1, Figure 1) to study and collect the local odonates.

\section{Collection methods}

We were in the field from dawn to dusk most days, although the bulk of our collecting activities took place after about 8 am, once odonates became more active. We walked existing forest trails and explored any suitable habitats - ponds, creeks, marshes, and swamps - we found. Odonates were spotted with the naked eye or with $7 \times$ and $10 \times$ binoculars, chiefly when up on trees or high vegetation. They were collected with green bag nets of $46 \mathrm{~cm}$ and $30 \mathrm{~cm}$ diameter, mounted on long $(1.80 \mathrm{~cm})$ and short $(1.20 \mathrm{~cm})$ aluminum telescopic handle poles. Field photographs were taken with a Canon 7d dsrl camera (Japan) and a Sigma $150 \mathrm{~mm}$ f 2.8 lens (Japan). For all specimens, detailed photos were taken, shortly after capture, against a standard white background from an X-Rite color checker that also features a $50 \mathrm{~mm}$ ruler on the left side (USA). The map was composed in QGIS v.2.8.3 (QGIS Development Team, 2018) using WorldClim elevation data (Hijmans et al., 2005) and the field coordinates were taken in degree format; also the annual average rainfall was obtained using the data provided by WorldClim for each locality. All the collected specimens are deposited at the Colección Entomológica de la Universidad de Antioquia (CEUA) in Medellín (Colombia). Here, they were identified by comparison with reference specimens and using specialized literature, mainly Garrison, von Ellenrieder, and Louton (2006, 2010) and Heckman (2006, 2008). Further, several generic revisions and species descriptions were consulted, including: Calvert (1909, 1924); Ris (1918); Kennedy (1938, 1941); Belle (1984); Dunkle (1986); Bick and Bick (1988); De Marmels (2001); Donnelly (1992); von Ellenrieder (2003, 2013); von Ellenrieder and Garrison (2003, 2017); Garrison (2004, 2006, 2009); Daigle (2005); Garrison and von Ellenrieder (2015, 2017); Tennessen (2015).

\section{Results}

A total of 291 specimens of 68 species were collected (Table 2). We confirmed Philogenia tinalandia Bick and Bick, 1988 as a junior synonym of Philogenia monotis (Kennedy, 1941). Further, we report the rediscovery of Philogenia raphaella Selys, 1886, Philogenia sucra

Table 2. List of species found during the trip - locality code, department and IUCN Category are reported.

\begin{tabular}{|c|c|c|c|c|c|}
\hline & Species & $\begin{array}{l}\text { Locality } \\
\text { code }\end{array}$ & Department & $\begin{array}{c}\text { IUCN } \\
\text { Category }\end{array}$ & Figure \\
\hline \multirow[t]{2}{*}{ Perilestidae } & Perissolestes cornutus (Selys, 1886) & SF,LI & $\mathrm{Pu}$ & $\mathrm{LC}$ & \\
\hline & $\begin{array}{l}\text { Perissolestes remotus (Williamson \& } \\
\text { Williamson, 1924) }\end{array}$ & $\mathrm{RN}$ & $\mathrm{Na}$ & LC & \\
\hline Platystictidae & Palaemnema picicaudata Kennedy, 1938* & LI & $\mathrm{Pu}$ & LC & $2 \mathrm{c}$ \\
\hline \multirow{5}{*}{ Calopterygidae } & Hetaerina aurora Ris, 1918 & $\mathrm{RN}$ & $\mathrm{Na}$ & $\mathrm{LC}$ & \\
\hline & Hetaerina caja caja (Drury, 1773) & JT & $\mathrm{Na}$ & NA & \\
\hline & Hetaerina occisa Hagen, 1853 & LS & $\mathrm{Ca}$ & NA & \\
\hline & Mnesarete fulgida (Selys, 1879) & IE & $\mathrm{Pu}$ & NA & \\
\hline & Mnesarete hauxwelli (Selys, 1869)* & IE,LI & $\mathrm{Pu}$ & NA & $2 b$ \\
\hline Dicteriadidae & Helioclaris amazona Selys, 1853 & VM & $\mathrm{Ca}$ & NA & \\
\hline \multirow[t]{3}{*}{ Heteragrionidae } & Heteragrion aequatoriale Selys, 1886 & $\mathrm{RN}$ & $\mathrm{Na}$ & $\mathrm{LC}$ & \\
\hline & Heteragrion bickorum (Daigle, 2005)* & IE & $\mathrm{Pu}$ & LC & $2 \mathrm{a}$ \\
\hline & Heteragrion inca Calvert, 1909 & IE,SF,LI & $\mathrm{Pu}$ & NA & \\
\hline Megapodagrionidae & Teinopodagrion curtum (Selys, 1886) & IE & $\mathrm{Pu}$ & $\mathrm{LC}$ & \\
\hline \multirow[t]{2}{*}{ Philogenidae } & Philogenia minteri Dunkle, 1986* & LI & $\mathrm{Pu}$ & LC & $2 \mathrm{f}$ \\
\hline & Philogenia monotis (Kennedy, 1941)* & $\mathrm{RN}$ & $\mathrm{Na}$ & $\mathrm{EN}$ & $2 \mathrm{~d}, \mathrm{e}$ \\
\hline
\end{tabular}


Table 2. Continued.

\begin{tabular}{|c|c|c|c|c|c|}
\hline & Species & $\begin{array}{l}\text { Locality } \\
\text { code }\end{array}$ & Department & $\begin{array}{l}\text { IUCN } \\
\text { Category }\end{array}$ & Figure \\
\hline & Philogenia raphaella Selys, 1886 & IE,LI & $\mathrm{Pu}$ & DD & $2 \mathrm{~h}, \mathrm{i}$ \\
\hline & Philogenia sucra Dunkle, 1986 & LS & $\mathrm{Ca}$ & DD & $2 \mathrm{j}$ \\
\hline \multirow{3}{*}{ Polythoridae } & Polythore conccina (McLachlan, 1881) & IE,LI & $\mathrm{Pu}$ & $\mathrm{LC}$ & \\
\hline & Polythore derivata (McLachlan, 1881) & $\mathrm{IE}$ & $\mathrm{Pu}$ & $\mathrm{LC}$ & \\
\hline & Stenocora percornuta Kennedy, $1940^{\dagger}$ & IE & $\mathrm{Pu}$ & NT & $3 a$ \\
\hline \multirow[t]{28}{*}{ Coenagrionidae } & Acanthagrion obsoletum (Förster, 1914) & $\mathrm{VM}$ & $\mathrm{Ca}, \mathrm{Pu}$ & LC & \\
\hline & Acanthagrion peruvianum Leonard, 1977 & LS & $\mathrm{Ca}$ & $\mathrm{LC}$ & \\
\hline & Acanthagrion trilobatum Leonard, 1977 & JT & $\mathrm{Na}$ & NA & \\
\hline & $\begin{array}{l}\text { Acanthallagma caeruleum Williamson \& } \\
\text { Williamson, } 1924\end{array}$ & $\mathrm{VM}$ & $\mathrm{Ca}$ & NA & \\
\hline & Amazoneura westfalli Machado, $2001^{\dagger}$ & LI & $\mathrm{Pu}$ & $\mathrm{LC}$ & $3 b$ \\
\hline & Argia difficilis Selys, 1865 & LI & $\mathrm{Pu}$ & NA & \\
\hline & Argia dives Förster, 1914 & IE,LI & $\mathrm{Pu}$ & $\mathrm{LC}$ & \\
\hline & Argia oculata Selys, 1865 & LI & $\mathrm{Pu}$ & $\mathrm{LC}$ & \\
\hline & Argia pulla Selys, 1865 & VM,LS,MO & $\mathrm{Ca}, \mathrm{Pu}$ & LC & \\
\hline & $\begin{array}{l}\text { Argia schneideri Garrison \& von } \\
\text { Ellenrieder, 2017* }\end{array}$ & IE & $\mathrm{Pu}$ & NA & $3 \mathrm{c}$ \\
\hline & $\begin{array}{l}\text { Calvertagrion mauffrayi (Tennessen, } \\
\text { 2015)* }\end{array}$ & RI & $\mathrm{Pu}$ & NA & $3 \mathrm{~g}, \mathrm{~h}$ \\
\hline & Drepanoneura laetitia (Donnelly, 1992)* & JT & $\mathrm{Na}$ & NA & \\
\hline & Enallagma novahispaniae Calvert, 1907 & VM & $\mathrm{Ca}$ & NA & \\
\hline & Epipleoneura venezuelensis Racenis, 1955 & VM & $\mathrm{Ca}$ & NA & \\
\hline & Ischnura capreolus (Hagen, 1861) & SF & $\mathrm{Pu}$ & NA & \\
\hline & Mecistogaster jocaste Hagen, 1869 & VM & $\mathrm{Ca}$ & NA & \\
\hline & $\begin{array}{l}\text { Metaleptobasis gabrielae von Ellenrieder, } \\
\text { 2013* }\end{array}$ & $\mathrm{VM}$ & $\mathrm{Ca}$ & DD & $3 d$ \\
\hline & Metaleptobasis mauffrayi Daigle, 2000 & LI,SF & $\mathrm{Pu}$ & LC & \\
\hline & Microstigma anomalum Rambur, 1842 & IE & $\mathrm{Pu}$ & NA & \\
\hline & Microstigma rotundatum Selys, 1860 & $\mathrm{IE}$ & $\mathrm{Pu}$ & NA & \\
\hline & Protoneura woytkowskii Gloyd, 1939* & IE & $\mathrm{Pu}$ & NA & $3 e$ \\
\hline & Psaironeura angeloi Tennessen, 2016 & JT & $\mathrm{Na}$ & NA & \\
\hline & Psaironeura bifurcata (Sjöstedt, 1918)* & LI & $\mathrm{Pu}$ & NA & $3 \mathrm{f}$ \\
\hline & Psaironeura tennuissima (Selys, 1886) & IE,LI & $\mathrm{Pu}$ & NA & \\
\hline & Telebasis carota Kennedy, 1936* & $\mathrm{IE}$ & $\mathrm{Pu}$ & NA & $3 \mathrm{k}$ \\
\hline & Telebasis flammeola Kennedy, 1936* & OR & $\mathrm{Pu}$ & EN & $3 \mathrm{j}$ \\
\hline & Telebasis griffinii (Martin, 1896) & VM & $\mathrm{Ca}$ & LC & \\
\hline & Telebasis versicolor Fraser, 1946 & VM & $\mathrm{Ca}$ & $\mathrm{LC}$ & \\
\hline \multirow[t]{2}{*}{ Aeshnidae } & Gynacantha litoralis Williamson, 1923 & OR & $\mathrm{Pu}$ & NA & \\
\hline & Gynacantha membranalis Karsch, 1891 & IE,SF & $\mathrm{Pu}$ & NA & \\
\hline \multirow[t]{17}{*}{ Libellulidae } & Triacanthagyna satyrus (Martin, 1909)* & SF & $\mathrm{Pu}$ & NA & $3 \mathrm{i}$ \\
\hline & Brechmorhoga vivax Calvert, 1906 & $\mathrm{RN}$ & $\mathrm{Na}$ & NA & \\
\hline & Erythemis vesiculosa (Fabricius, 1775) & SF & $\mathrm{Pu}$ & LC & \\
\hline & Erythrodiplax abjecta (Rambur, 1842) & JB & $\mathrm{Na}$ & NA & \\
\hline & Erythrodiplax attenuata (Kirby, 1889) & RI & $\mathrm{Pu}$ & NA & \\
\hline & Erythrodiplax basalis (Kirby, 1897) & $\mathrm{LS}, \mathrm{OR}, \mathrm{MO}, \mathrm{RC}, \mathrm{SF}$ & $\mathrm{Ca}, \mathrm{Pu}$ & NA & \\
\hline & Erythrodiplax fusca (Rambur, 1842) & LS,RC,SF & $\mathrm{Ca}, \mathrm{Pu}$ & NA & \\
\hline & Erythrodiplax latimaculata Ris, 1911 & MO & $\mathrm{Pu}$ & NA & \\
\hline & Erythrodiplax umbrata (Linnaeus, 1758) & LS,SF & $\mathrm{Ca}, \mathrm{Pu}$ & NA & \\
\hline & Erythrodiplax unimaculata (De Geer, 1773) & $\mathrm{RC}$ & $\mathrm{Pu}$ & NA & \\
\hline & Gynothemis pumila (Karsch, 1889) & VM & $\mathrm{Ca}$ & LC & \\
\hline & Miathyria marcella (Selys, 1857) & $\mathrm{RC}$ & $\mathrm{Pu}$ & LC & \\
\hline & Misagria parana Kirby, 1889 & $\mathrm{VM}$ & $\mathrm{Ca}$ & NA & \\
\hline & Nephepeltia phryne (Perty, 1834) & $\mathrm{RC}$ & $\mathrm{Pu}$ & LC & \\
\hline & Orthemis cultriformis Calvert, 1899 & JT,IE & $\mathrm{Na}, \mathrm{Pu}$ & NA & \\
\hline & Uracis fastigiata Burmeister, 1839 & IE,LI & $\mathrm{Pu}$ & NA & \\
\hline & Uracis imbuta Burmeister, 1839 & OR & $\mathrm{Pu}$ & NA & \\
\hline Gomphidae & Phyllogomphoides brunneus Belle, 1981* & IE & $\mathrm{Pu}$ & NA & $2 \mathrm{~g}$ \\
\hline
\end{tabular}

Note: The bold species are the new records for the country.

First records of the genus in Colombia; *first records of the species in Colombia.

Abbreviations: Ca, Cauca department; Na, Nariño department; Pu, Putumayo department; NA, not assessed; LC, least concern; NT, near threatened; EN, endangered; DD, data deficient. 


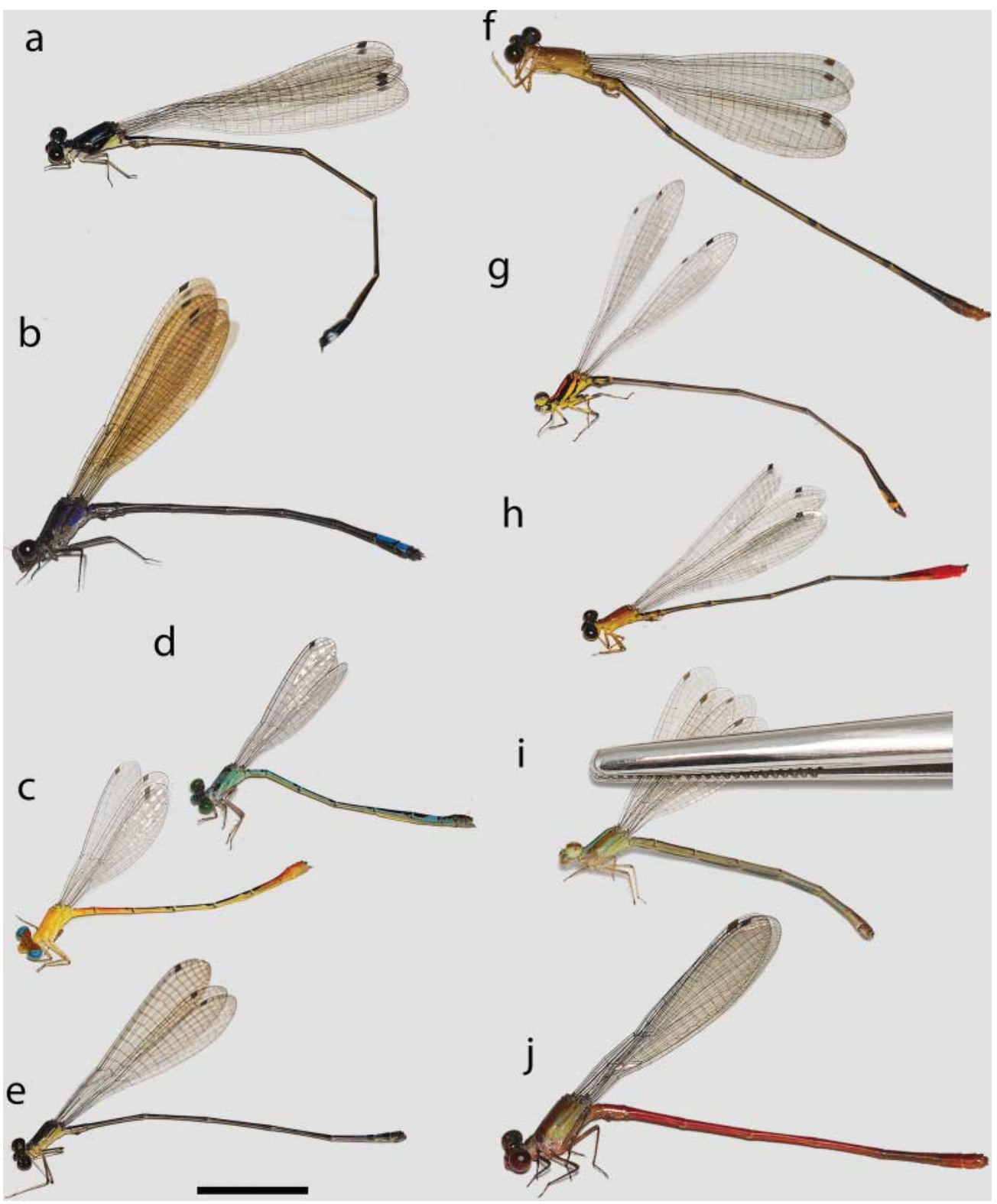

Figure 2. New Odonata species recorded for Colombia. Coenagrionidae: a) Amazoneura westfalli Vereda El Libano, Putumayo 22 Jan 2017; b) Argia schneideri La Isla Escondida reserve, Putumayo 20 Jan 2017; c) and d) Calvertagrion mauffrayi island on Putumayo river close to Puerto Leguizamo, Putumayo 31 Jan 2017, both female, c) is an immature specimen; e) Depranoneura letitia close to Tumaco, Nariño 18 Feb 2017; f) Metaleptobasis gabrielae Vereda Miraflor, Cauca 23 Jan 2017; g) Protoneura woytkowskii La Isla Escondida reserve, Putumayo 20 Jan 2017; h) Psaironeura bifurcata La Isla Escondida reserve, Putumayo 20 Jan 2017; i) Telebasis flammeola Orito, Putumayo 15 Jan 2017, female; j) Telebasis carota La Isla Escondida reserve, Putumayo 20 Jan 2017. Photos Michele Viganò.

Dunkle, 1986 and Stenocora percornuta Kennedy, 1940, after 131, 48 and 77 years respectively. Also, 17 species were recorded for the first time in Colombia (Figures 2-4), two of them are records for new genera for the country (Stenocora percornuta Kennedy, 1940 and Amazoneura westfalli Machado, 2001). The new species for Colombia belong to the following families 


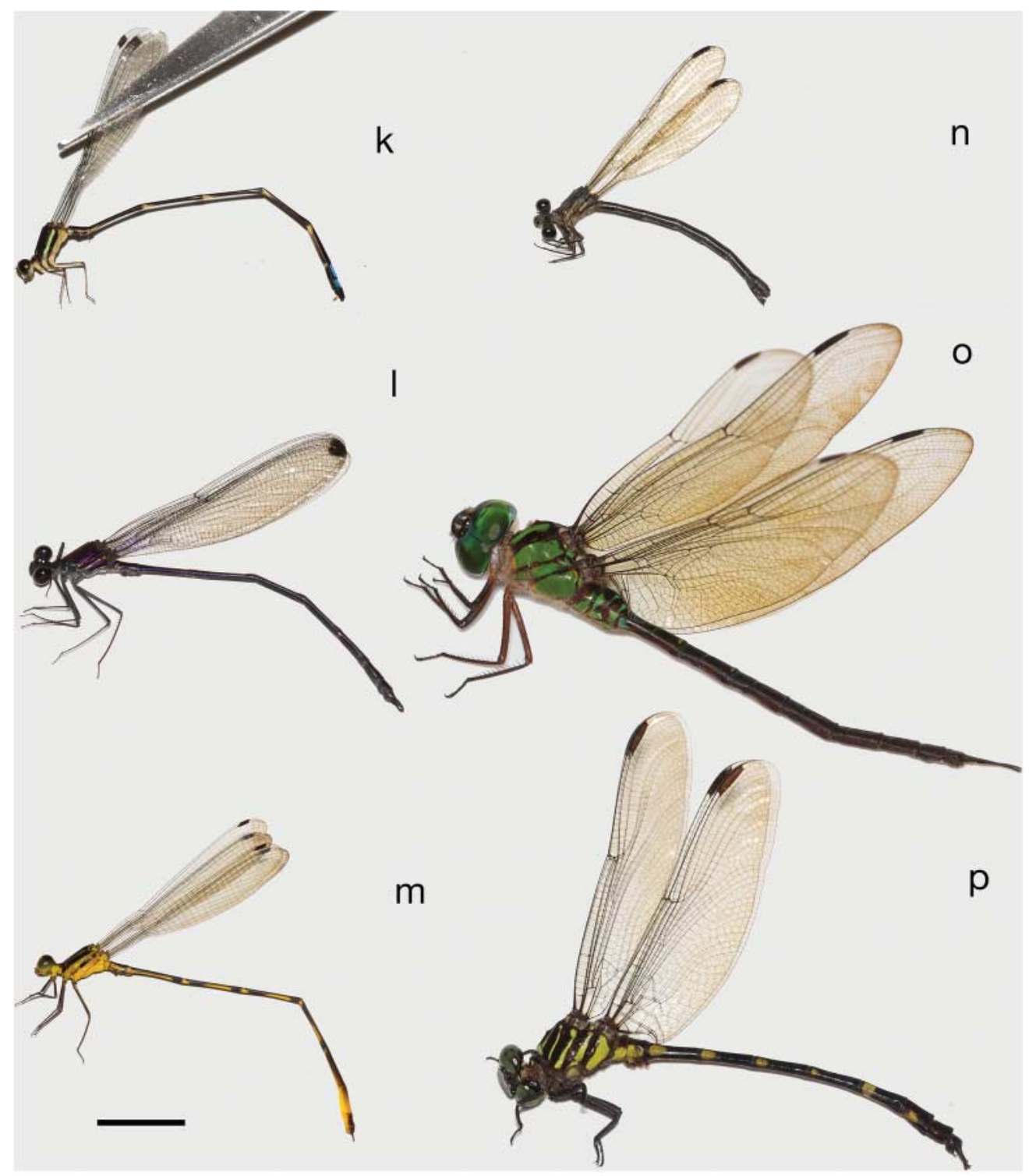

Figure 3. New Odonata species recorded for Colombia. Plastyctidae: k) Palaemnema picicaudata Vereda El Libano, Putumayo 22 Jan 2017; Calopterygidae: 1) Mnesarete hauxwelli La Isla Escondida reserve, Putumayo 18 Jan 2017; Heteragrionidae: m) Heteragrion bickorum Vereda El Libano, Putumayo 22 Jan 2017; Polythoridae: n) Stenocora percornuta La Isla Escondida reserve, Putumayo 19 Jan 2017, female; Aeshnidae: o) Tricanthagyna satyrus Vereda San Francisco, Putumayo 30 Jan 2017; Gomphidae: p) Phyllogomphoides brunneus La Isla Escondida reserve, Putumayo 17 Mar 2017. Photos Michele Viganò.

and species: Coenagrionidae (Amazoneura westfalli, Argia schneideri, Calvertagrion mauffrayi, Drepanoneura laetitia, Metaleptobasis gabrielae, Protoneura woytkowskii, Psaironeura bifurcata, Telebasis carota, and Telebasis flammeola) (Figure 2), Platystictidae (Palaemnema picicaudata), Calopterygidae (Mnesarete hauxwelli), Heteragrionidae (Heteragrion bickorum), Polythoridae (Stenocora percornuta), Aeshnidae (Triacanthagyna satyrus) and Gomphidae (Phyllogomphoides brunneus) (Figure 3), Philogenidae (Philogenia minteri and Philogenia monotis) (Figure 4). Our records raise the number of odonate species known from the country 


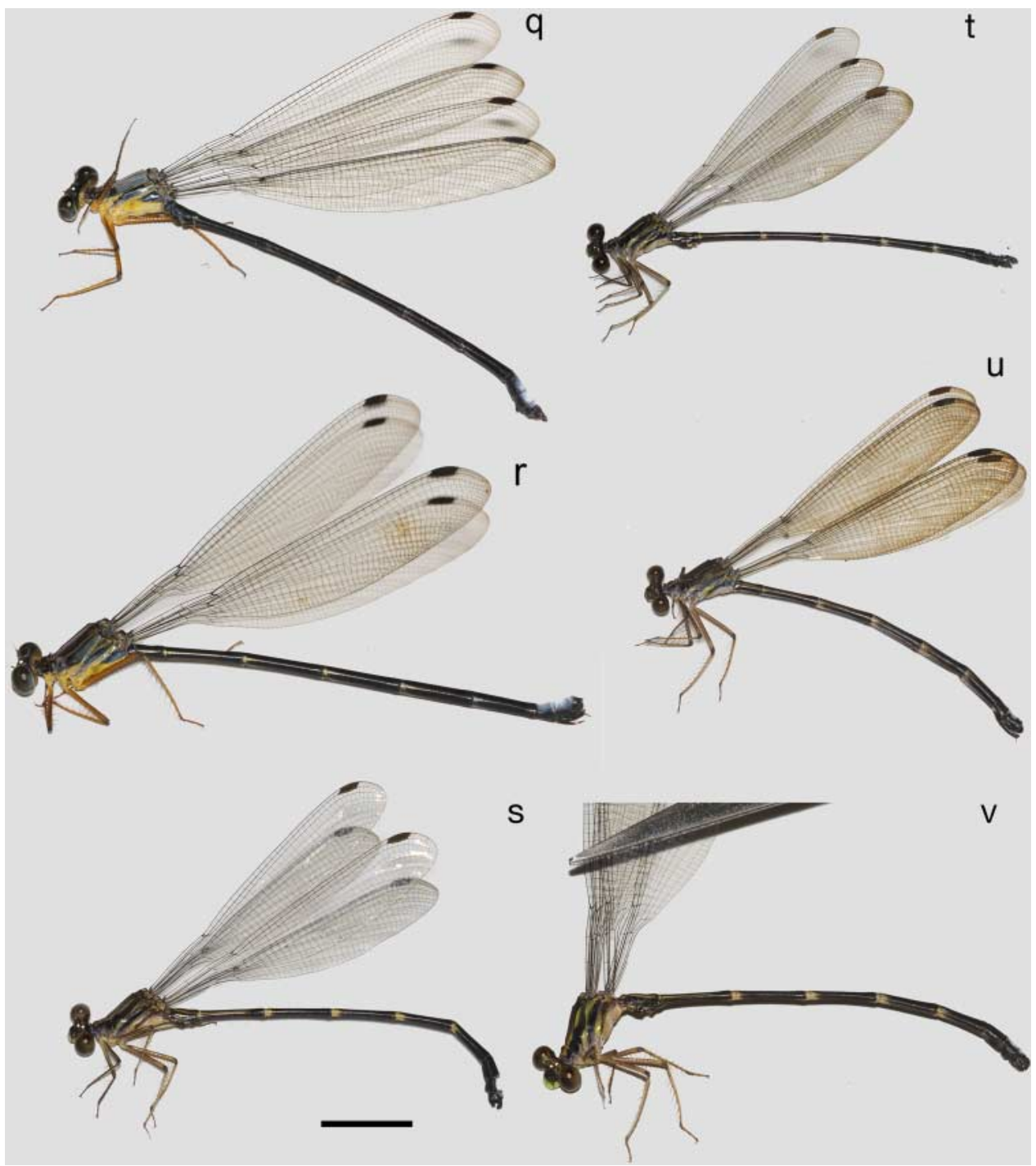

Figure 4. New Odonata species recorded for Colombia and other Philogenia specimens. Philogenidae: q) and r) Philogenia monotis Rio Nambì reserve, Nariño 17 Feb 2017, respectively male and female; s) Philogenia sucra Vereda la Sevilla, Cauca 25 Jan 2017; t) and u) Philogenia raphaella La Isla Escondida reserve, Putumayo 19 Jan 2017, respectively male and female; v) Philogenia minteri Vereda El Libano, Putumayo 22 Jan 2017. Photos Michele Viganò.

to 423. The number of records in the departments of Cauca, Nariño and Putumayo are increased respectively to 34,17 and 69 (Table 2).

\section{Discussion}

\section{Rare and/or endangered species}

Of the 68 species found, 30 have been assessed by the IUCN Red List. Most are listed as Least Concern, but six of the species we recorded are under some threat status. Three are listed as Data Deficient, two as Endangered and one as Near Threatened: 
Philogenia raphaella and $P$. sucra, the only Colombian endemics of the six threatened, are rediscovered after 131 and 48 years respectively, since they were first collected (Bick \& Bick, 1988; Dunkle, 1986). Both are listed as Data Deficient because they were only known from their respective type localities (Bota-Sierra, Palacino, \& Rache, 2016; Bota-Sierra, Palacino, Rache, \& von Ellenrieder, 2016). Our records are the first since these species were described. Further, P. raphaella was described in 1886 from a single male labeled "Bogotá", a catch-all locality for specimens that were collected elsewhere (Bota-Sierra \& Novelo-Gutiérrez, 2017). Our record is the first to be associated with a specific locality, which fortunately falls within a protected area. P. sucra was only known from Caquetá department; therefore, our records from Cauca expand its range approximately $100 \mathrm{~km}$ to the southwest. Cueva de los Guácharos National Park lies between these two sites, and we expect $P$. sucra to occur there.

We suspect that $P$. raphaella is the senior synonym of Philogenia redunca Cook, 1989. Following Calvert's (1924) key, we easily identified our specimens as $P$. raphaella; in order to confirm we read Selys's original description which also matches our specimens perfectly (Selys, 1886); however, reviewing Cook's description of $P$. redunca, we find that our specimens also match his types perfectly (Cook, 1989). Additionally, the type locality of $P$. redunca is Yanamanaca (Napo province, Ecuador), only approximately $150 \mathrm{~km}$ south of Orito, where we collected our specimens. Nevertheless, the drawings of the type of $P$. raphaella by P. L. Whitycombe in Calvert's paper are not as accurate as Cook's illustrations for $P$. redunca. Therefore, a revision of the holotype of $P$. raphaella in the BMNH is needed in order to clarify this issue and will be the target of our future studies.

The third data deficient species we found is Metaleptobasis gabrielae von Ellenrieder, 2013, a recently described species known from a single locality, Tamshiyacu-Tahuayo Reserve in Loreto department, Peru (von Ellenrieder, 2013). Our finding expands its range approximately $700 \mathrm{~km}$ to the northeast. Several protected areas - La Paya National Park in Colombia and the GüeppiSekime National Park and Ampiyacu Regional Conservation Areas in Peru - lie between these two sites, and M. gabrielae is likely to occur there as well.

The two species listed as Endangered were both believed to be endemic to Ecuador: Philogenia monotis and Telebasis flammeola Kennedy, 1936 (Tennessen \& Mauffray, 2016a, 2016b). We discussed $P$. monotis - for which $P$. tinalandia is the junior synonym - above, and our records expand its distribution about $500 \mathrm{~km}$ to the north. It has now been documented in three protected areas: the Tinalandia reserve in Ecuador, the Río Nambí Nature Reserve and Farallones de Cali National Park in Colombia. T. flammeola was only known from three localities in the Amazonian foothills of eastern Ecuador. In one of these areas, its habitat recently disappeared due to intensive agriculture (Tennessen \& Mauffray, 2016b). Here we report its presence in Putumayo department, a northward range expansion of about $150 \mathrm{~km}$; unfortunately, the site where we found it is an unprotected area also under threat from intensive agriculture.

Finally, S. percornuta, in a monotypic genus, is listed as Near Threatened, as it was only known from three localities on the east slope of the Andes in Peru and Ecuador. Its most recent record dates back to 1940 (von Ellenrieder, 2009); therefore, our rediscovery of the species in a protected area approximately $150 \mathrm{~km}$ north of its previously known distributional limit is excellent news for its conservation.

\section{Philogenia monotis and Philogenia tinalandia synonymy}

Kennedy (1941) described Agnophilogenia monotis from a female collected on 8 March 1941, at Lorena, close to Santo Domingo de los Colorados (Pacific slope of the northern Ecuadorian Andes in Pichincha province, Ecuador). Bick and Bick (1988) described P. tinalandia on the basis of two males collected on 13 May 1985, also near Santo Domingo de los Colorados 
and only $3 \mathrm{~km}$ away from the type locality of A. monotis. von Ellenrieder (2003) examined these type specimens and showed that the characters used by Kennedy to describe the genus Agnophilogenia fall within the range of variation of the species of the genus Philogenia. She thus synonymized these genera and suggested that $P$. tinalandia was probably a junior synonym of $P$. monotis, but as neither type series included both sexes, she concluded: "whether $P$. tinalandia is a junior synonym of $P$. monotis or whether they represent separate species is a question that will be answered once a series including both males and females is collected within the area E of San Domingo de Los Colorados." The surprise here is that the answer did not come from Santo Domingo de los Colorados, but from Colombia, where we found two new populations of this species: one located in Nariño department, at the Rio Nambi nature reserve (approximately $250 \mathrm{~km}$ north of the type locality), the second in Valle del Cauca department, in the Farallones de Cali National Park (approximately $500 \mathrm{~km}$ north of the type locality) (Figure 1). In both locations males and females were found together (some were collected while mating), the males perfectly matching the description of $P$. tinalandia and the females perfectly matching P. monotis, confirming that von Ellenrieder (2003) was correct. Indeed, based on the examination of the following specimens, we conclude that $P$. tinalandia is a junior synonym of $P$. monotis:

COLOMBIA: $3 \circ$ and $20^{7}$, Nariño department, Barbacoas municipality, Río Nambi Reserve, $1.29853^{\circ} \mathrm{N} 78.08317^{\circ} \mathrm{W}, 1400 \mathrm{~m}$ asl, 17 February 2017, M. Vigano, A. Corso \& O. Janni Leg.; 1 \% and $10^{7}$, Valle del Cauca department, Dagua municipality, Farallones de Cali National Park, 3,57493 N 76, $89015^{\circ} \mathrm{W}, 956 \mathrm{~m}$ asl, 9 May 2017, J. Sandoval Leg.

The data collected on this expedition are a significant contribution to the knowledge of the dragonfly diversity in Colombia. We strongly encourage researchers interested in Odonata and other taxonomic groups to contribute their distributional records, as this information remains limited for many areas of Colombia and for many taxa. Better and more complete data is vital for improving assessments of conservation status and the implementation of conservation actions.

\section{Acknowledgements}

We are grateful to the Grupo de Entomología de la Universidad de Antioquia, especially to Yenny Correa, for their help with lab logistic in CEUA, and to Natalia von Ellenrieder who shared literature and advice during the writing process. For help with fieldwork, we would like to thank Jurgen Beckers (Reserva Natural La Isla Escondida), Manuel Cuasialpud (Orito, Putumayo), Alexis Ruiz Burbano and Gerlando Delgado Bermeo (Piamonte, Cauca), Flor Peña (Puerto Leguizamo, Putumayo), Mauricio Pai Florez and Fundacion FELCA (Reserva Natural Rio Nambi). AC wishes to thanks LEICA Sport Optics for the loaning of the optical instruments used during the trip.

\section{ORCID}

Cornelio A. Bota-Sierra (D) http://orcid.org/0000-0002-6555-7913

Juliana Sandoval-H. (D) http://orcid.org/0000-0002-9369-2717

\section{References}

Avendaño, J. E., Cuervo, A. M., López-O., J. P., Gutiérrez-Pinto, N., Cortés-Diago, A., \& Cadena, C. D. (2015). A new species of tapaculo (Rhinocryptidae: Scytalopus) from the Serranía de Perijá of Colombia and Venezuela. The Auk, 132(2), 450-466. https://doi.org/10.1642/AUK-14-166.1

Belle, J. (1984). A synopsis of the South American species of Phyllogomphoides, with a key and descriptions of three new taxa (Odonata, Gomphidae). Tijdschrift Voor Entomologie, 127(4), 79-100.

Bick, G. H., \& Bick, J. C. (1988). A review of males of the genus Philogenia, with descriptions of five new species from South America (Zygoptera: Megapodagrionidae). Odonatologica, 17(1), 9-32.

Bota-Sierra, C. A. (2014). A brief look at the Odonata from the Páramo ecosystems in Colombia, with the descriptions of Oxyallagma colombianum sp. nov. and Rhionaeschna caligo sp. nov. (Odonata: Coenagrionidae, Aeshnidae, Libellulidae). Zootaxa, 3856(2), 192-210. 
Bota-Sierra, C. A. (2017). Two new species of the family Philogeniidae (Odonata: Zygoptera) from the Western Colombian Andes. International Journal of Odonatology, 20(3-4), 137-150. https://doi.org/10.1080/13887890. 2017.1344733

Bota-Sierra, C. A., Maufray, B., Palacino-Rodríguez, F., Hofmann, J., Tennessen, K. J., Rache, L., \& Tognelli, M. F. (2016). Estado de conservación de las libélulas de los Andes Tropicales. In M. F. Tognelli, C. A. Lasso, C. A. BotaSierra, L. F. Jiménez-Segura, \& N. A. Cox (Eds.), Estado de Conservación y Distribución de la Biodiversidad de Agua Dulce en los Andes Tropicales (pp. 67-86). Gland, Suiza, Cambridge, UK y Arlington, USA: UICN. https:// doi.org/10.2305/IUCN.CH.2016.02.es

Bota-Sierra, C. A., Moreno-Arias, C., \& Faasen, T. (2015). Preliminary list of Odonata from the Colombian Amazon, with descriptions of Inpabasis nigridorsum sp. nov. \& Diaphlebia richteri sp. nov. (Coenagrionidae \& Gomphidae). International Journal of Odonatology, 18(3), 249-268.

Bota-Sierra, C. A., \& Novelo-Gutiérrez, R. (2017). The genus Heteragrion (Odonata: Zygoptera) in Northwestern Colombia, with the description of Heteragrion tatama sp. Nov. Zootaxa, 4347(3), 553-571. https://doi.org/10.11646/ zootaxa.4347.3.8

Bota-Sierra, C. A., Palacino, F., \& Rache, L. (2016). Philogenia raphaella. Retrieved from http://doi.org/10.2305/IUCN. UK.2016-1.RLTS.T49254336A49256325.en

Bota-Sierra, C. A., Palacino, F., Rache, L., \& von Ellenrieder, N. (2016). Philogenia sucra. Retrieved from http://doi. org/10.2305/IUCN.UK.2016-1.RLTS.T158930A66887616.en

Bota-Sierra, C. A., Rache, L., \& Palacino, F. (2016). Telebasis farcimentum. Retrieved from http://doi.org/10.2305/IUCN. UK.2016-1.RLTS.T49254321A49255457.en

Calvert, P. P. (1909). Contributions to a knowledge of the Odonata of the Neotropical region, exclusive of Mexico and Central America. Annals of the Carnegie Museum, 6(3), 73-280.

Calvert, P. P. (1924). The generic characters and the species of Philogenia Selys (Odonata: Agrionidae). Transactions of the American Entomological Society, 50, 1-56. Retrieved from https://www.jstor.org/stable/25077099?seq = 1\#page _scan_tab_contents

Cook, C. (1989). Philogenia redunca, a new damselfly from Ecuador (Odonata: Megapodagrionidae). Florida Entomologist, 72(3), 419-428. Retrieved from http://journals.fcla.edu/flaent/article/view/58516

Daigle, J. J. (2005). Heteragrion bickorum spec. nov. from Ecuador (Zygoptera: Megapodagrionidae). Odonatologica, 34(2), 165-168.

De Marmels, J. (2001). Revision of Megapodagrion Selys, 1886:(Insecta, Odonata: Megapodagrionidae). Universität Zürich.

Donnelly, T. W. (1992). The Odonata of Central Panama and their position in the neotropical odonate fauna, with a checklist, and descriptions of new species. In D. Quintero \& A. Aiello (Eds.), Insects of Panama and Mesoamerica: selected studies (pp. 52-90). New York: Oxford University Press.

Dunkle, S. W. (1986). Four new species of Philogenia damselflies from Ecuador and Colombia (Zygoptera: Megapodagrionidae). Odonatologica, 15(1), 43-50.

Garrison, R. W. (2004). An analysis of the Psaironeura tenuissima complex, including synonymy of $P$. machadoi De Marmels with P. bifurcata Sjöstedt (Zygoptera: Protoneuridae). Odonatologica, 33(1), 83-89.

Garrison, R. W. (2006). A synopsis of the genera Mnesarete Cowley, Bryoplathanon gen. nov., and Ormenoplebia gen. nov. (Odonata: Calopterygidae). Contributions in Science, 506, 1-84.

Garrison, R. W. (2009). A synopsis of the genus Telebasis (Odonata: Coenagrionidae). International Journal of Odonatology, 12(1), 1-121.

Garrison, R. W., \& von Ellenrieder, N. (2015). Damselflies of the genus Argia of the Guiana Shield (Odonata: Coenagrionidae). Zootaxa, 4042(1), 1-134. https://doi.org/10.11646/zootaxa.4042.1.1

Garrison, R. W., \& von Ellenrieder, N. (2017). New species of the damselfly genus Argia from Mexico, Central America and Ecuador with an emphasis on Costa Rica (Insecta: Odonata: Coenagrionidae). Zootaxa. https://doi.org/10.11646/ zootaxa.4235.1.1

Garrison, R. W., von Ellenrieder, N., \& Louton, J. A. (2006). Dragonfly genera of the New World: an illustrated and annotated key to the Anisoptera. Baltimore: Johns Hopkins University Press.

Garrison, R. W., von Ellenrieder, N., \& Louton, J. A. (2010). Damselfly Genera of the New World: An Illustrated and Annotated Key to the Zygoptera. Johns Hopkins University Press. Retrieved from https://books.google.com.mx/books?id = OpQpAQAAMAAJ

Heckman, C. W. (2006). Encyclopedia of South American aquatic insects: Odonata-Anisoptera: illustrated keys to known families, genera, and species in South America. Springer Science \& Business Media.

Heckman, C. W. (2008). Encyclopedia of South American aquatic insects: Odonata-Zygoptera: illustrated keys to known families, genera, and species in South America. Olympia, WA: Springer Science \& Business Media.

Hijmans, R. J., Cameron, S. E., Parra, J. L., Jones, P. G., \& Jarvis, A. (2005). WORLDCLIM - a set of global climate layers (climate grids). International Journal of Climatology, 25, 1965-1978. Retrieved from http://www.worldclim. org/

Hoffmann, J. (2009). Summary catalogue of the Odonata of Peru: kommentiertes Faksimile des Manuskripts von J. COWLEY, Cambridge, 20.05. 1933 und aktuelle Liste der Odonaten Perus mit Fundortangaben sowie Historie zu Sammlern und Odonatologen in Peru. Retrieved from http://www.dragonflyfund.org/images/reports/IDF_Report_16_Hoff mann_Cowley_2009_small.pdf

Kennedy, C. H. (1938). Palaemnema picicaudata, P. abbreviata and P. brucelli, new dragonflies from Ecuador, with notes on other Palaemnemas (Odonata: Platystictidae). Annals of the Entomological Society of America, 31(2), 249-266. 
Kennedy, C. H. (1941). Agnophilogenia monotis, new genus and species of dragonfly from humid northwestern Ecuador (Odonata: Megapodagrioninae). Annals of the Entomological Society of America, 34(2), 490-494.

Lara, C. E., Cuervo, A. M., Valderrama, S. V, Calderón-f, D., \& Cadena, C. D. (2012). A new species of wren (Troglodytidae: Thryophilus) from the dry Cauca River Canyon, northwestern Colombia. The Auk, 129(3), 537-550.

Paulson, D. R. (2004). Critical species of Odonata in the Neotropics. International Journal of Odonatology, 7(2), 163188.

Pérez-Gutiérrez, L. A., \& Palacino-Rodríguez, F. (2011). Updated checklist of the Odonata known from Colombia. Odonatologica, 40(3), 203-225.

QGIS Development Team. (2018). QGIS Geographic Information System. Open Source Geospatial Foundation Project. https://doi.org/http://www.qgis.org/

Rache, L. (2015). Primer registro del género Aeschnosoma Selys, 1871 (Odonata: Corduliidae) para Colombia. Entomotropica, 30(2015), 224-226.

Rangel-ch, J. O. (2005). La biodiversidad de Colombia. Palimpsestos, 5, 292-304. https://doi.org/10.1073/pnas. 262413599

Ris, F. (1918). Libellen (Odonata) aus der Region der amerikanischen Kordilleren von Costarica bis Catamarca. (E. Strand, Ed.). Archiv für Naturgeschichte.

Selys-Longchamps, E. (1886). Revision du Synopsis des Agrionines. Première partie comprenant les légions Pseudostigma, Podagrion, Platycnemis et Protoneura. Mémoires Couronnés et Autres Mémoires, Académie Royale de Belgique, 38(4), 1-233.

Stiles, F. G., Laverde-R, O., \& Cadena, C. D. (2017). A new species of tapaculo (Rhinocryptidae: Scytalopus) from the Western Andes of Colombia. The Auk, 134(2), 377-392.

Tennessen, K. J. (2015). Four new species of Calvertagrion St. Quentin from South America (Odonata: Coenagrionidae). Odonatologica, 44(3), 397-430.

Tennessen, K. J., \& Mauffray, W. (2016a). Philogenia monotis. Retrieved from http://doi.org/10.2305/IUCN.UK.2016-1. RLTS.T49254398A49256317.en

Tennessen, K. J., \& Mauffray, W. (2016b). Telebasis flammeola. Retrieved from http://doi.org/10.2305/IUCN.UK.2016-1. RLTS.T49254565A49255465.en

Vivas-Santeliz, J., \& De Marmels, J. (2017). Current knowledge of Odonata in Venezuela: Diversity and distribution of endemic taxa. Odonatologica. https://doi.org/10.5281/zenodo.572355

von Ellenrieder, N. (2003). A synopsis of the Neotropical species of "Aeshna" Fabricius: the genus Rhionaeschna Förster (Odonata: Aeshnidae). Tijdschrift Voor Entomologie, 146(1), 67-207. https://doi.org/10.1163/22119434-900000120

von Ellenrieder, N. (2009). Stenocora percornuta. Retrieved from http://doi.org/10.2305/IUCN.UK.2009-2.RLTS.T5977 5A12017582.en.

von Ellenrieder, N. (2013). A revision of Metaleptobasis Calvert (Odonata: Coenagrionidae) with seven synonymies and the description of eighteen new species from South America. Zootaxa (Vol. 3738). https://doi.org/10.11646/zootaxa. 3738.1.1

von Ellenrieder, N., \& Garrison, R. W. (2003). A synopsis of the genus Triacanthagyna (Odonata: Aeshnidae). International Journal of Odonatology, 6(2), 147-184.

von Ellenrieder, N., \& Garrison, R. W. (2017). A synopsis of the Neotropical genus Protoneura (Odonata: Coenagrionidae). Zootaxa, 4361(1), 1-76. 